UDC 595.771(470+571)

LBC 28.691.89(2Rus)

\title{
FAUNAL AND ECOLOGICAL FEATURES \\ OF BLOOD-SUCKING ARTHROPODS OF THE FAMILY IXODIDAE IN BIOCENOSES OF THE LOWER VOLGA REGION
}

\author{
Andrey A. Denisov \\ Volgograd State University, Volgograd, Russian Federation
}

\begin{abstract}
Ecological and faunal changes caused by physical and geographical changes, climatic, anthropogenic impacts, lead to an increase in the number and spread of Ixodes mites. The above mentioned factors have a significant impact on the formation of the fauna of bloodsucking arthropods in bio and agrocenoses, as well as in settlements. The study of the mechanisms that impact on the spatial distribution, timing of breeding and mass attack of the bloodsuckers on proximately, the change of life the schemes of the parasites in different climatic and geographic areas is of considerable theoretical and practical interest for veterinary and medical practices. For ixodid distinctive relationship with a particular landscape type and occurrence within certain habitats. That is why these types of blood-sucking ectoparasites are able to pass to parasitism on new feeders. The development of civilization is accompanied by an active transformation of nature, as a result of which large areas disappear landscapes previously untouched by human hand. Naturally, such transformations, accompanied by the creation of anthropogenic landscapes, can not in one way or another affect the nature of the spread of zoonoses and, above all, natural focal infections, most closely related to the environment. The obtained data can be used by veterinary and medical services, as well as biologists of profile appointment in the planning of preventive measures of diseases associated with blood-sucking arthropods.
\end{abstract}

Key words: parasitology, Ixodes mites, Lower Volga region.

УДК 595.771(470+571)

ББК 28.691.89(2Poc)

\section{ФАУНИСТИЧЕСКАЯ И ЭКОЛОГОЧЕСКАЯ ОСОБЕННОСТЬ КРОВОСОСУЩИХ ЧЛЕНИСТОНОГИХ СЕМЕЙСТВА IXОDIDAE В БИОЦЕНОЗАХ ЗОНЫ НИЖНЕГО ПОВОЛЖЬЯ}

\author{
Андрей Александрович Денисов \\ Волгоградский государственный университет, г. Волгоград, Российская Федерация
}

\begin{abstract}
Аннотация. Эколого-фаунистические изменения, вызванные физико географическими изменениями, климатическими, антропогенными воздействиями, приводят к росту численности и расширенному распространению иксодовых клещей. Выше указанные факторы оказывают существенное влияние на формирование фауны кровососущих членистоногих в био и агроценозах, а так же и населенных пунктах. Изучение ح. механизмов этого воздействия на биотопическое распределение, сроки выплода и массового нападения 훙 кровососов на прокормителей, изменение жизненных схем паразитов в условиях разных климатических и \& географических территорий представляет значительный теоретический и практический интерес для ветеринарной и медицинской практики. Для иксодид характерна связь с определенным типом ландшафта, встреча\% емость в границах определенных биотопов. Именно поэтому данные виды кровососущих эктопаразитов и способны переходить к паразитированию на новых прокормителях. Развитие цивилизации сопровождается 肎 активным преобразованием природы, в результате которого на больших площадях исчезают ландшафты, (2) ранее нетронутые рукой человека. Естественно, такие преобразования, сопровождающиеся созданием ант-
\end{abstract}


ропогенных ландшафтов, не могут тем или иным образом не сказаться на характере распространения зоонозов и, прежде всего, природно-очаговых инфекций, наиболее тесно связанных с окружающей средой. Полученные данные могут быть использованы ветеринарными и медицинскими службами, а также биологами профильного назначения при планировании профилактических мероприятий заболеваний связанных с кровососущими членистоногими.

Ключевые слова: паразитология, иксодовые клещи, Нижнее Поволжье.

Введение. В зоне Нижнего Поволжья зарегистрировано 14 видов иксодовых клещей, которые участвуют в природной очаговости трансмиссивных болезней на данной территории. Жизненный цикл переносчиков, продолжающийся от яйца до имаго включительно, составляет одну генерацию (поколение). Число таких поколений в умеренной зоне Нижнего Поволжья у разных видов может быть от одного до нескольких в год, но у отдельных видов процесс развития одного поколения затягивается на 23 года. В жизненных циклах кровососов важное эпидемиологическое значение имеют особенности гонотрофических циклов и гонотрофической гармонии. Гонотрофический цикл (например, период от одной кладки яиц до другой у низших двукрылых - комаров, мошек, и др.) включает поиск хозяина и нападение на него, питание и созревание яиц, поиск мест для их откладки. Первый гонотрофический цикл (после появления имаго) не всегда требует приема крови. У части видов кровососов и в отдельных популяциях конкретных видов может наблюдаться развитие яиц без приема крови на имагинальной фазе. По числу проделанных гонотрофических циклов определяют физиологический возраст переносчиков. Увеличение числа таких циклов, то есть возрастание физиологического возраста, увеличивает потенциальную опасность переносчиков. В понятие «гонотрофическая гармония» входит соответствие между количеством выпитой крови и числом развивающихся яиц.

Болезни циркулирующие в очагах могут быть облигатно трансмиссивными, то есть обязательно передающимися через переносчиков (например, Конго-крымская лихорадка, передающаяся через иксодового клеща), и факультативно трансмиссивными, то есть передающимися разными путями (с участием переносчиков или без них, например, туляремия). Так на территории Нижнего Поволжья на се- годняшний день зарегистрировано большое количество трансмиссивных заболеваний бактериального и вирусного характера, одними носителей и переносчиков которых являются кровососущие членистоногие семейства Ixodidae.

Клещи встречаются в самых разнообразных географических ландшафтах, входя в состав свойственных им фаун в качестве сочленов биоценозов различных биотопов, в тундре, лесной зоне, степях, полупустынях, пустынях и в горных районах, где свойственны свои виды иксодовых клещей.

Изучать клещей в России начали в конце 19-го века. Сначала они являлись объектами чисто зоологических исследований. Несколько позднее они привлекли внимание ветеринаров и медиков и им были посвящены публикации многих авторов [8; 9]. Особую важность при выявлении распространения фауны иксодовых клещей связанную с тем, что иксодиды являются высоко специализированными паразитами наземных позвоночных животных, и в первую очередь млекопитающих и птиц. Данное семейство клещей привлекают пристальное внимание исследователей как переносчики и длительные хранители возбудителей многих бактериальных, вирусных, риккетсиозных и протозойных заболеваний человека и животных [1;7]. Для выяснения причин и условий существования природного очага любой трансмиссивной инфекции необходимо, как это вытекает из учения академика Е.Н. Павловского знание видового состава, биологии и экологии основных источников и переносчиков возбудителя заболевания.

Ввиду того, что иксодовые клещи характеризуются повсеместным распространением, географическое распространение иксодид, как временных эктопаразитов зависит от условий окружающей среды, распространения их прокормитилей и отражает историю формирования фауны конкретного региона. 
К настоящему времени с разной степенью точности установлено географическое распространение большинства видов иксодовых клещей $[4 ; 5 ; 6]$.

Среди более 40000 описанных видов клещей (Acari) семейство клещей (Ixodidae) представляет небольшую группу, состоящую из 680 видов, относимых к 2 подсимействам и 14 родам. По литературным данным на сегодняшнее время на территории России зарегистрировано 6 родов иксодовых клещей: Rhipicephalus, Ixodes, Boophilus, Dermacentor, Haemophysalis, Hyaloтта и около 60 видов [1; 7].

В связи с тем, что иксодовые клещи представляют собой группу высоко специалезировынных кровососущих членистоногих эктопаразитов, которые имеют первостепенное ветеринарное и медицинское значение, являясь переносчиками и резервуарами возбудителей всевозможных заболеваний, то необходимо изучение и определение видовой и родовой принадлежности иксодовых клещей паразитирующих на животных и человеке в той или иной географической зоне. Так как это имеет важное значение для принятия эпидемиологических и эпизоотологичеких решений по предупреждению распространения кровопаразитарных и других заболеваний среди сельскохозяйственных, диких животных и человека $[2 ; 3 ; 8 ; 9 ; 11 ; 12 ; 13]$.

Материалы и методы. Данный материал был получен после проведения исследований на территории Саратовской, Волгоградской и Астраханской областях входящих в зону Нижнего Поволжья в период с 2000 по 2010 годы. В природе голодных иксодовых клещей всех фазах развития собирали на маршрутах, в разных биотопах: в пойменных леcax по опушкам, поросших балках, лесополосах, по обвалованиям оросительных систем и т. д., непосредственно с растительности и почвы. Сборы клещей проводили в солнечную погоду в утренние часы при отсутствии росы и при слабом ветре. В пасмурные дни сборы проводили в дневные часы. Вылов иксодовых клещей проводили на флажок из фланелевой ткани насаженную на древко. Через 20-25 шагов флаг и одежду сборщика осматривали на наличие иксодовых клещей, так как клещи могут нападать на человека. Пойманных клещей складыва- ли по 20 штук в лабораторные пробирки и закрывали ватномарлевыми пробками. Чтобы клещи не высохли, в каждую пробирку клали несколько свежесорванных травинок. Сбор иксодовых клещей мы также производили с сельскохозяйственных животных. Клещей с крупного рогатого скота собирали в населенных пунктах (частные), на фермах и пастбищах в присутствии хозяина или ответственного лица. Осмотр коров производили во время утренней или вечерней дойки. Клещей с животных снимали руками в тонких резиновых перчатках. Снятых клещей сортировали по пробиркам, напившихся складывали не больше 10 в одну пробирку, которые недавно прикрепились и не успели насосаться крови, упаковывали по 20 штук в одну пробирку. В пробирки вкладывали этикетки, в которых указывали дату, количество осмотренных животных, место сбора. Весь собранный полевой материал разбирали и определяли в лаборатории особоопасных инфекций «Центра гигиены и эпидемиологи по Волгоградской области» и в лаборатории кафедры «Инфекционная патология и судебно ветеринарная медицина» зооветеринарного факультета Волгоградской государственной сельскохозяйственной академии. Иксодовых клещей после доставки в лабораторию, разбирали по видам, используя бинокулярную лупу, стереомикроскоп и определители по иксодовым клещам [10].

Обсуждение результатов. Территория Нижнего Поволжья простирается по нижнему течению p. Волги (см. таблицу). Нижнее Поволжье в целом расположено в юго-восточной части Русской платформы. Ее северная половина выполнена меловыми и третичными отложениями, южная часть сложена мезозоем и палеогеном, и наконец, на юго-востоке - неогеном и четвертичными породами (Прикаспийская низменность).

Общность территории обусловлена также самим волжским бассейном, где Волга и ее притоки являются стержнем Нижнего Поволжья. Несмотря на климатические различия, главным образом в широтном направлении, Нижние Поволжье обладает многими общими чертами климата, обусловленными удаленностью от Атлантики, близостью к Сибири и Средней Азии, - суровостью зимы и общей континен- 
тальностью, проявляющихся в разной степени в отдельных местах Нижнего Поволжья.

Здесь четко выражена широтная зональность и отмечается последовательный переход от лесной зоны до пустынь умеренного пояса.

Засушливость и континентальность климата увеличивается с северо-запада на юговосток. В этом же направлении отмечается уменьшение величин стока и увеличивается засоленность вод небольших рек.

Эта закономерность выражена и в формировании бассейна главной водной артерии Волги, имеющей в северных районах разветвленную сеть притоков, число которых к югу резко сокращается. Южнее устья реки Еруслан, в полупустынной и пустынной зонах Волга притоков не принимает.

Для этой же части территории характерны местные бессточные бассейны, например, озера Баскунчак, Эльтон, Сарпинских озеро, рек Большого и Малого Узень и других. В северных районах Поволжья большое значение имеет осушение, а на юге - орошение и обводнение территорий.

Из полученных нами результатов исследований установлено, что на территории Нижнего Поволжья, куда входят Саратовская, Волгоградская и Астраханская области нами зафиксировано 6 родов иксодовых клещей.

Как видно из таблицы 1 фауна иксодид Саратовской области зарегистрированных при наших исследованиях составила 5 родов. Эти рода представлены 12 видами: Dermacentor
(D. reticulatus Fabricius, D. marginatus Sulzer, D. niveus Neumann), Haemaphysalis punctata Can.et Fanz, Hyalomma (H. marginatum Koch, H. scupense Schulze), Rhipicephalus (Rh. rossicus Jakimov et Kohl-Jakimova, Rh. schuzei Olenev), Ixodes (I. ricinus Linnaeus, I. laguri Olenev, I. crenulatus Koch I. persulcatus Schulze).

Наши наблюдения свидетельствуют, что на территории Саратовской области доминирующими видами являются клещи рода Dermacentor. Более массовое распространение по данной территории имеет вид $D$. reticulatus, нашедший благоприятные условия на территориях 20 районов области и в зеленых зонах г. Саратова (ИД = 33,86 \%), а (ИД $=26,31)$ составили иксодовые клещи D. marginatus. Вид D. niveus, был недавно обнаружен в наших сборах, но количество его было незначительно. Достаточно распространенными видами являются клещи рода Ixodes.Их можно отнести к субдоминантам на данной территории. Так (ИД = 21,40 \%) составили клещи I. ricinus, a I. persulcatus (ИД $=15,93 \%$ ) соответственно. Остальные виды составили незначительную массу от общего количества в наших сборах.

Из общего числа собранных иксодовых клещей на территории Волгоградской области обитает 12 видов клещей семейства Ixodidae, относящихся к 5 родам указанных в таблице 1: Ixodes (I. ricinus Linnaeus, I. laguri Olenev, I. crenulatus Koch), Dermacentor (D. marginatus Sulzer, D. reticulatus Fabricius,

Рода иксодовых клещей зоны Нижнего Поволжья

Таблийа

\begin{tabular}{|c|c|}
\hline $\begin{array}{c}\text { Субъекты РФ, относящиеся к зоне } \\
\text { Нижнего Поволжью }\end{array}$ & Рода иксодовых клещей \\
\hline \multirow[t]{5}{*}{ Саратовская } & Dermacentor \\
\hline & Haemaphysalis \\
\hline & Hyalomma \\
\hline & Rhipicephalus \\
\hline & Ixodes \\
\hline \multirow[t]{5}{*}{ Волгоградская } & Ixodes \\
\hline & Dermacentor \\
\hline & Rhipicephalus \\
\hline & Hyalomma \\
\hline & Haemophisalis \\
\hline \multirow[t]{5}{*}{ Астраханскя } & Dermacentor \\
\hline & Rhipicephalus \\
\hline & Hyalomma \\
\hline & Haemophisalis \\
\hline & Boophilus \\
\hline
\end{tabular}


D. pictus Hermann), Rhipicephalus (Rh. rossicus Jakimov et Kohl-Jakimova, Rh. pumilio Schulze, Rh. schuzei Olenev), Hyalomma (H. marginatum Koch, H. scupense Schulze), Haemophisalis punctata Canestrini et Fanzago.

Количественное распределение видов клещей в фауне Волгоградской области крайне неравномерно. Доминирующее по численности и встречаемости положение занимают клещи из рода Hyalomma, виды H. scupense (ИД $=38,95 \%)$ и $H$. marginatum (ИД = 27,88 \%). Субдоминантами в фауне иксодид Волгоградской области оказались клещи из рода Dermacentor $-D$. reticulatus $($ ИД $=$ $16,74 \%$ и и. marginatus (ИД $=15,83 \%$ ). Многочисленным видом иксодовых клещей является Rhipicephalus rossicus (ИД = 7,53\%). Эти пять видов иксодовых клещей в области по численности составляют 98,53\% от всей фауны клещей Волгоградской области. К очень редким видам иксодовых клещей для фауны области нами отнесены Ixodes crenulatus (coбрано всего 9 экземпляров за 10 лет исследований), Rhipicephalus pumilio (21 экз.) и Rhipicephalus schulzei (18 экз.)

На территории Астраханской области в наших сборах зарегистрировано 13 видов иксодовых клещей семейства Ixodidae, также относящихся к 5 родам указанных в таблице 1: Dermacentor (D. marginatus Sulzer, D. reticulatus Fabricius, D. daghestanicus Schulze), Rhipicephalus (Rh. rossicus Jakimov et Kohl-Jakimova, Rh. pumilio Schulze, Rh. sangwineus, Rh. bursa), Hyalomma (H. marginatum Koch, H. scupense Schulze, $H$. asiaticum, $H$. impressum Olenev), Haemophisalis (H. punctata Canestrini et Fanzago), Boophilus (B. calcaratus Birula).

Количественное распределение видов иксодовых клещей на территории Астраханской области является, как и на территории Волгоградской области неравномерным. Доминирующее по численности и встречаемости положение занимают клещи из рода Hyalomma, так виды H. scupense (ИД = $28,75 \%$ ), H. marginatum (ИД =25,81\%). Субдоминирующими видами в фауне иксодид Астраханской области явились клещи из рода Dermacentor $D$. daghestanicus $($ ИД = $15,02 \%$ ), и D. marginatus (ИД $=13,04 \%$ ). Одним из многочисленных видов иксодовых клещей на территории Астраханской области, как и на территории Волгоградской области, является Rhipicephalus rossicus (ИД $=9,23 \%)$. На данной территории эти виды иксодовых клещей составели 88,34 и $53,04 \%$ от всей фауны иксодид зарегистрированных нами на территории Астраханской области. Не типичными видами для Астраханской области являются иксодовые клещи Hyalomma impressum за все годы исследования нами зарегистрировано 13 экз. и Boophilus calcaratus 9 экз.

Заключение. Представленные данные наших исследований свидетельствуют о том, что на всей территории Нижнего Поволжья, которая состоит из трех областей: Саратовской, Волгоградской и Астраханской наблюдается достаточно большое разнообразие в видовом отношении иксодовых клещей, которые представлены 26 видами из 6 родов. Доминирование иксодовых клещей меняется с севера на юг. Так в северной зоне Нижнего Поволжья доминантами являются иксодовые клещи рода Dermacentor. Продвигаясь дальше на юг по территории Нижнего Поволжья доминирование переходит к клещам рода Hyalomma.

\section{СПИСОК ЛИТЕРАТУРЫ}

1. Балашов, Ю. С. Иксодовые клещи-паразиты и переносчики инфекций / Ю. С. Балашов. - СПб. : Наука, 1998. - 285 c.

2. Давидович, В. Ф. Иксодовые клещи в Саратовской области и их роль в поддержании микроочагов туляремии / В. Ф. Давидович // Медицинская паразитология и паразитарные болезни. 1971. - № 4. - C. 470-475.

3. Колонин, Г. В. Мировое распределение иксодовых клещей род Haemaphysalis / Г. В. Колонин. - М. : Наука, 1978. - 72 с.

4. Колонин, Г. В. Мировое распределение иксодовых клещей род Ixsodes / Г. В. Колонин. - М. : Наука, 1981. - 116 c.

5. Колонин, Г. В. Мировое распределение иксодовых клещей роды Dermacentor, Anocentor, Cosmiomma, Dermocentonomma, Boophilus, Margaropus, Nosomma, Ripicentor, Rhipicephalus, Margaropus, Anomalohimalaya / Г. В. Колонин. М. : Наука, 1984. -96 c.

6. Колонин, Г. В. Мировое распределение иксодовых клещей роды Hyalomma, Aponomma, Amblyomma / Г. В. Колонин. - М. : Наука, 1983. - 121 с. 
7. Кербабаев, Э. Б. Основы ветеринарной акарологии. Методы и средства борьбы с клещами / Э. Б. Кербабаев // Труды ВИГИС. - 1998. - Т. 34. С. 68-112.

8. Павловский, Е. Н. О синтезе учения о природной очаговости болезней и теории паразитоценозов / Е. Н. Павловский // Журнал микробиологии, эпидемиологии и иммунологии. - 1957. - № 7. C. $11-18$.

9. Павловский, Е. Н. Природная очаговость трансмиссивных болезней / Е. Н. Павловский. - М. : Наука, 1964. - 211 с.

10. Филиппова, Н. А. Иксодовые клещи подсемейства Ixodinae / Н. А. Филиппова. - СПб. : Наука, 1977. - 396 c.

11. Ticks reservoir of piroplasms in Central and Northern Italy / A. Iori, S. Gabrielli, P. Calderini, A. Moretti, M. Pietrobelli, M. Tampieri, R. Galuppi, G. Cancrini // J. Article. Vet. Parasitol. - 2010. - P. 27.

12. Franke, J. Exploring gaps in our knowledge on Lyme borreliosis spirochaetes - updates on complex heterogeneity, ecology, and pathogenicity/ J. Franke, A. Hildebrandt, W. Dorn // Ticks Tick Borne Dis. 2012. - Vol. 4. - P. 11-25.

13. Research on the ecology of ticks and tickborne pathogens- methodological principles and caveats / A. Estrada-Peca, J. S. Gray, O. Kahl, R. S. Lane // Frontiers in Cellular and Infection Microbiology. 2013. - Vol. 1. - P. 3-29.

\section{REFERENCES}

1. Balashov Ju.S. Iksodovye kleshhi-parazity $i$ perenoschiki infekcij. Saint Petersburg, Nauka, 1998. $285 \mathrm{p}$.

2. Davidovich V.F. Iksodovye kleshhi v Saratovskoj oblasti i ih rol' v podderzhanii mikroochagov tuljaremii [Ixode mites in the Saratov region and their role in maintaining micro-foci of tularemia]. Medicinskaja parazitologija i parazitarnye bolezni, 1971, no. 4, pp. 470-475.
3. Kolonin G.V. Mirovoe raspredelenie iksodovyh kleshhej rod Haemaphysalis. Moscow, Nauka, 1978. 72 p.

4. Kolonin G.V. Mirovoe raspredelenie iksodovyh kleshhej rod Ixsodes. Moscow, Nauka, 1981. 116 p.

5. Kolonin G.V. Mirovoe raspredelenie iksodovyh kleshhej rody Dermacentor, Anocentor, Cosmiomma, Dermocentonomma, Boophilus, Margaropus, Nosomma, Ripicentor, Rhipicephalus, Margaropus, Anomalohimalaya. Moscow, Nauka, 1984.96 p.

6. Kolonin G.V. Mirovoe raspredelenie iksodovyh kleshhej rody Hyalomma, Aponomma, Amblyomma. Moscow, Nauka, 1983. 121 p.

7. Kerbabaev Je.B. Osnovy veterinarnoj akarologii. Metody i sredstva borby s kleshhami. Trudy VIGIS, 1998, vol. 34, pp. 68-112.

8. Pavlovskij E.N. O sinteze uchenija o prirodnoj ochagovosti boleznej i teorii parazitocenozov [About the synthesis of the doctrine of natural focality of diseases and the theory of parasitocenosis]. Zhurnal mikrobiologii, jepidemiologii $i$ immunologii, 1957, no. 7, pp. 11-18.

9. Pavlovskij E.N. Prirodnaja ochagovost transmissivnyh boleznej. Moscow, Nauka, 1964. 211 p.

10. Filippova N.A. Iksodovye kleshhi podsemejstva Ixodinae. Saint Petersburg, Nauka, 1977. $396 \mathrm{p}$.

11. Iori A., Gabrielli S., Calderini P., Moretti A., Pietrobelli M., Tampieri M., Galuppi R., G. Cancrini. Ticks reservoir of piroplasms in Central and Northern Italy. J. Article. Vet. Parasitol, 2010, p. 27.

12. Franke J., Hildebrandt A., Dorn W. Exploring gaps in our knowledge on Lyme borreliosis spirochaetes - updates on complex heterogeneity, ecology, and pathogenicity. Ticks Tick Borne Dis, 2012, vol. 4, pp. 11-25.

13. Estrada-Peca A., Gray J.S., Kahl O., Lane R.S. Research on the ecology of ticks and tick-borne pathogens - methodological principles and caveats. Frontiers in Cellular and Infection Microbiology, 2013, vol. 1, pp. 3-29.

\section{Information about the Author}

Andrey A. Denisov, Candidate of Sciences (Biology), Associate Professor, Department of Ecology and Nature Resources Management, Volgograd State University, prosp. Universitetskiy, 100, 400062 Volgograd, Russian Federation, adenisov18@yandex.ru.

\section{Информация об авторе}

Андрей Александрович Денисов, кандидат биологических наук, доцент кафедры экологии и природопользования, Волгоградский государственный университет, просп. Университетский, 100, 400062 г. Волгоград, Российская Федерация, adenisov18@yandex.ru. 